\title{
Macrothink
}

\section{How Leadership and Mentoring Enhance the Quality of Teaching and Learning in Higher Education}

\author{
Ahmed Mohammed Arbab \\ Ph.D., FHEA, SFHEA, Vice Dean \\ College of Administrative Sciences, Applied Science University \\ P.O Box 5055, Kingdom of Bahrain, \\ E-mail: ahmed.arbab@asu.edu.bh
}

Received: October 16, 2018 Accepted: December 18, 2018 Published: February 19, 2019

doi:10.5296/ijld.v9i1.13814

URL: https://doi.org/10.5296/ijld.v9i1.13814

\begin{abstract}
This paper presents lessons drawn from senior fellowship of the Higher Education Academy, United Kingdom (SFHEA) with regard to leadership and mentoring. The paper integrates various elements of leadership and mentoring that needed for enhancing the quality of teaching and learning in Higher Education. In this article, I have adopted a holistic methodology to reflect my teaching and supporting learning experience (almost 35 years) in higher education as inspired from the SFHEA, UK. Evidence of my successful engagement across all five areas of activity will be provided that include firstly, design a series of teaching and learning activities to meet the learning outcomes of a module. Secondly, use a range of teaching approaches to enhancing student learning. Thirdly, use a variety of assessment for learning activities for students and providing feedback to promoting student engagement. Fourthly, develop effective learning environments and approaches to student support and guidance. Fifthly, engage in continuing professional development (CPD) in subjects /disciplines and their pedagogy, incorporating research, scholarship and the evaluation of professional practices. Moreover, I show my understanding of the appropriate core knowledge and demonstrating my commitment to the professional values. This paper contributes by providing and demonstrating a thorough understanding of effective approaches to learning and teaching support as a key contribution to high quality student learning. In addition to providing evidences of successful leadership, co-ordination, support, supervision, management and/or mentoring of others (whether individuals and/or teams) in relation to learning and teaching.
\end{abstract}

Keywords: Leadership, Mentoring, Quality of Teaching and Learning, Higher Education, Senior Fellowship SF, Higher Education Academy HEA, UK, Kingdom of Bahrain 


\section{Introduction}

The writing process has led me to reflect on the influence of my earliest learning experiences. Living in school hostel gave me the confidence to be an independent person and developed my leadership skills. Later when I got my $\mathrm{PhD}$ and joined academia, I developed my abilities and started to lead and impact on other colleagues in the different positions held.

I entered the teaching profession as a teaching assistant following the attainment of my Bachelor's degree in Business Administration from the University of Khartoum, Sudan in 1983. My degree provided me knowledge and skills to begin my teaching career. After a period as a teaching assistant, I was promoted to a lecturer shortly after getting my Master's degree in Business Administration from the University of Wales UK in 1989. Although I had good knowledge of my subject and an understanding of Higher Education, my understanding of learning and teaching was limited to personal reflections. I had no experience of university processes, however, with my colleagues' support, guidance, and workshops, I developed rapidly designing and delivering a new module and becoming an academic advisor for 80 students. This was a turning point for me. I became a very competent teacher with good communication skills. Colleagues and students provided positive feedback; my modules have always remained attractive to students. My philosophy of teaching which values integrity, respect, fairness, perseverance, and aspiration served my students and me well.

Fourteen years of experience in Sudan led to other posts including coordinator of Owner Management in Technical and Administrative Training Institute (TATI) in Muscat, instructor in Management Technology Department, Qatar College of Technology (QTC) and a Dean of Faculty of Administrative \& Financial Sciences at Delmon University in Bahrain. In these jobs, I progressively developed more coordinating, managerial and leadership roles influenced by the work of (Richard, Georgy, \& Jonathan, 2007; Simon, 2015; Hoffmeyer, Sheingold, Hester, Klopper, \& Warland, 2015). In addition, my reflections on leadership styles (e.g. democratic, laissez-faire, autocratic, transactional, and transformational) were present. I was especially inspired by the work of Bryman (2007) who identifies eleven facets of leadership in Higher Education including providing direction, creating a structure to support the direction, and fostering a supportive and collaborative environment. Moreover, Bryman adds, establishing trustworthiness as a leader, having personal integrity, having credibility to act as a role model, facilitating participation in decision-making and effective consultation are all important. In addition, Bryman writes about providing communication about developments, representing the department/institution to advance its cause(s) and networking on its behalf, respecting existing cultures while seeking to instill values through a vision for the department/institution and protecting staff autonomy. Bryman's thinking aligns with my value-base: I am a transformational leader. The examples of my practice explained in this paper is an evidence of the sustained record of my leadership as an initiator, supporter, coordinator, facilitator, supervisor, manager, and mentor of others.

\section{Literature Review \& Discussion}

There are over 400 definitions of leadership. George \& Colin (1995) state that Leadership is a matter of making a difference. They added that Leadership is a relationship through which one 
person influences the behaviour or actions of other people. Moreover, Hoffmeyer et al. (2015) argue that developing leaders and leadership are key factors to improve learning and teaching in higher education. In addition, Quinlan (2014) influenced me with his proposal about what is needed for sound educational leadership in higher education is leadership of teaching for student learning. On the other hand, the mentoring scheme is distinct from the academic career development review Scheme. Mentors give informal and frequent advice and provide a listening ear throughout the year, whereas formal academic career development review meetings take place annually and are normally conducted by the head of department. Importantly, the mentor cannot be the one holding the academic career development review meeting (Cindy, 2004). Mentoring aims to give academic staff guidance on how to make effective use of their career within the Higher Education institution both for their own development and for their contribution to their Higher Education institution. To benefit from mentoring, mentees should be receptive to the advice and encouragement that the mentor can offer. Therefore, the relationship must be a positive and trusting one (De Janasz, \& Sullivan, 2004). Effective mentoring is about building a supportive relationship based on listening, mutual respect and trust. It requires skills and sensitivity on both sides, (Savage, Rashelle, \& Logue, 2010).

One of the leading role I faced when I was appointed as a Programme Leader for the Master of Human Resource Management (MHRM) in 2013. My role was to develop the MHRM Programme. This was a challenging role. In doing that, I have been influenced by the work of Khaled et al. (2013) who state that the review and redesign of the curriculum must be based on expert opinion focused on two main aspects: first, the relevance of the programme to the needs of local and regional industry and second, its comparability to similar programmes. Case Study (1) provides further details about my role in leading this change.

I developed my knowledge and skills by attending workshops on different topics delivered by experts from the Australian Universities Quality Agency, the Kingdom of Bahrain, and Yarmouk University. The topics included programme design, assessment and feedback and benchmarking. I then used my knowledge to co-ordinate, oversee and coach staff I was responsible for as (Siddique, Aslam, Khan, and Urooj, 2011) explained how a leader should act. For example, in my role as the Head of the Programme \& Curriculum Review Committee, I coordinated workshops on course planning, teaching methods, exams setting, assessment, quality assurance, and self-evaluation in Higher Education. I was able to identify development in their practices as a result of the workshops. I also got positive feedback from individuals who I coached one to one. Having developed my own approach to teaching based on my philosophy and role models who influenced my thinking, I support my colleagues, so they could learn to facilitate learning rather than release material. To do this, I needed to coach individuals who were unsure of their practice. For example, one of my colleagues came to my office and asked me about how to improve feedback from students. I provided him with guidance on teaching, learning and assessment. This impacted on the performance of students as reported in their official feedback in the course evaluation report (CER). Accordingly, my colleagues' performance was enhanced significantly (Sally, 2007; Abdeldayem, 2018).

These experiences determined my decision to be a leader in higher education and confirmed 
myself confidence, which supported in my decision. Quinlan (2014) introduces a model of leadership, which sees that universities should intentionally promote holistic student learning and development. Furthermore, since 2014 I have developed my role as a mentor to newly appointed academic staff, building my approach on my philosophy of teaching and approach to learning (See Case Study 2). For example, I led several workshops that brought new staff together, so they could learn about the university together and form a supportive community. Positive feedback on this approach has fed through to annual appraisals. In addition, as a Vice Dean, I noticed improvement in their teaching, learning, assessment, and research activity, evidenced in reports from the Dean of the College of Administrative Sciences, course evaluation reports (CER) and Annual Program Review Reports (APRR).

After completing the Balanced Scorecard Professional (BSP) Certification, I developed my leadership role further, supporting both academic and administrative staff to build the Balanced Scorecard Professional (BSC) framework into their specialization - academic or administrative - to improve the strategic planning process of the university. The outcome of this has increased transparency across the university of what the organizational objectives are and how they can be met.

My supportive role also allowed me to mentor colleagues on tasks such as mapping the Bachelor in Business Administration Programme to NQF Levels using NQF Descriptors. I have also mentored two colleagues who have applied for the status of Fellow of the Higher Education Academy (See Case Study 2).

My postgraduate studies have enabled me to promote the involvement of some colleagues in research. For instance, I have encouraged the creation of research groups to find solutions for Bahraini organizations in the area of Human Resource Management. To do this, I set up a meeting, including Human Resource managers, the Programme Advisory Board and staff participating in the MHRM Programme. The meeting discussed the current challenges facing the practice of HR in Bahraini organizations. I led the meeting enabling participants to talk with each other. The main recommendation of the meeting was to increase the use of research in teaching and learning and to promote staff publication of research. I have monitored the impact of the changes I led which included creating a base of research that could be used by students in their research projects. There has also been a significant increase in the number of published research papers in the international peer reviewed journal $(25 \%+)$. For example, I co-authored a paper with my student entitled "The Impact of Talent Management Strategies on Enhancement of Competitive Advantage in Bahrain Post" published in the International Journal of Core Engineering \& Management in 2017. I also co-authored a paper with one colleague entitled "Does Information Technology Affect Improvement of Human Resources Directorate's Performance in a Selected Organization in the Kingdom of Bahrain?" published in the International Business and Management, 2017. Moreover, I have used these publications as part of teaching and learning to support student learning as suggested by (Dietz, Jansen \& Wadee, 2006). This has influenced my colleagues; they are currently using their own publications in teaching. The annual meeting with MHRM students identified the positive impact of my Programme Leadership on their learning and development. 


\section{Macrothink}

I have attended many conferences such as Art \& Science of Doing Research, Multilevel Models of Creativity, and Mastering Creativity: Principles \& Practice and Three Golden Rules for Successful Scientific Research. These conferences influenced my thinking about leadership and supporting staff research activity. Accordingly, I published an article entitled "the Impact of Comprehensive Quality Efficiency on Training Programmes in Sudanese Universities", in the European Journal of Business and Management, 2016. Moreover, I used what I had learned to influence and impact on practice of both my colleagues and students through the formation of three research groups to deal with the challenges facing the practice of HR in Bahraini organizations. In addition, I have supervised master theses and have been an external examiner for several master theses. This provided me with opportunities to provide support and consultancy on developing courses and research beyond my institution.

Because of my leadership abilities and effectiveness record, I was promoted as the Vice Dean of the College of Administrative Sciences in 2017, a role in which I chaired five committees and had the opportunity to lead and mentor members of staff. The role I played in both leading $\&$ mentoring others as a Vice Dean has a clear impact on the entire College of Administrative Sciences. I meet staff regularly and share with them best practices. This style of management has been very satisfactory to my colleagues and encouraged them to be very interactive. Individuals observed a sense of belonging and feeling of commitment that was reported to senior leaders. The impact of my leadership has been felt not only by staff, but also by students who said on many occasions, and in their formal feedback that they were experiencing a significant improvement in teaching, learning, assessment, and classroom management since my appointment as a Vice Dean. The College Council responded to the positive student feedback, with one senior member saying, "Dr Arbab, we are living in the golden era of this College".

Due to the above-distinguished achievements, the University's Senior Management assigned to me three panels for Programme Periodic Review. I coordinated each one to focus on standards of excellence, while helping staff build positive relationships. I received a letter of commendation on the success of my leadership from the University's Quality Assurance \& Accreditation Centre. I am part of the leadership teams across the University, including the College Council, College Management Committee, University Academic Standards and Examination Committee, University Student Experience Committee, Quality Assurance and Accreditation Council, and Academic Audit Committee. My involvement in these committees has given me experience in making decisions that affect across the university and has helped me support and mentor colleagues. I continue to get positive feedback from Senior Staff and the individuals for whom I am responsible about the way I lead and inspire people.

\section{Case Studies in Leadership and Mentoring in Higher Education}

As I stated earlier in this paper, reflections have revealed how much my transformational style of leadership has impacted on both colleagues and students in enhancing the quality of teaching, and the students experience across the higher education institution. Moreover, examining the UK Professional Standards Framework for teaching and supporting learning in higher education (the five areas of activity, core knowledge and professional values) and fitting my 
personal and academic experience and leadership within is UKPSF, a turning point towards further development in my leadership and mentoring roles in higher education. The subsequent Case Studies reflect on this in more depth, both as an academic leader and as a mentor different higher education initiation.

\subsection{Case Study (1): Leading the Master of Human Resource Management Programme}

In 2013, I was promoted to the position of Programme leader of Master of Human Resource Management (MHRM) at ASU. This was a challenging task. Duties covered all aspects related to the designing and functioning of the MHRM Programme. My overall aim was the development of a relevant, coherent, and deliverable curriculum within the required time scales. This case study explores my collaboration with stakeholders, especially staff, employers and programme advisory board as we worked to redesign the programme (Gary, 2008).

The re-development of the MHRM programme was driven by the labour market needs. I had good evidence that a high number of companies and governmental bodies lack specialists in HR. This confirmed the need for the programme but also made it clear that I needed highly qualified academic staff to deliver it and that the curriculum needed to be fit for purpose. Developing a programme must reflect standards required by the National Authority for Qualifications and Quality Assurance of Education \& Training of the Kingdom of Bahrain (2012), ASU vision and mission, and labor market needs. Based on the above, the programme must also be developed in a local framework with stakeholders, which include employers, alumni, students, staff, and university management (Pegg, Waldock, Sonia, \& Lawton, 2012).

Leading the design of the MHRM Programme at ASU offered me the chance to operationalize my ideas about theoretical understanding, practical application, problem solving, analytical skills, communication, and competence (autonomy, responsibility, and context) across the programme as suggested by (Sharon, Roland, Jerrold, \& Leroi, 2010). I worked with the programme team to develop an action plan, key performance indicators, timeline, budget, and a clear responsibility for every member in the team. In addition, I developed a framework with stakeholders (employers, practitioners, managers, alumni, and relevant university staff). I provided clear guidelines and support for achieving the task within the time framework. Having done that, I called a large meeting at the university. My role was to get stakeholders actively involved. I was influenced by the work of Simon (2015) and his conclusion that "Higher Education leaders need a combination of leadership and management competencies in order to address the challenges faced in the sector; separation of these facets is counterproductive and will not address the negative impact of managerialism perceived within institutions". In addition to, the large meeting, stakeholders were consulted by way of a small piloting group. I realized that they needed to be more involved in the design process. Accordingly, I appointed two groups for MHRM namely: a programme team and an advisory board. Both groups included stakeholders to ensure a sense of ownership and to allow each group members to participate. The two groups were expert in their areas (Lorraine, Eric, Elena, $\&$ Monica, 2016). However, this exposed me to challenges such as the ambiguity of the groups' boundaries and variabilities in the groups' keenness, interest, and commitment. For example, during programme team and advisory board meetings, I observed that some influential voices 
were very loud. I believed that massive group debate would not achieve agreement but would consume the little available planning time. I also believed that the programme would gain from clear and simple viewpoints; however, I had observed that a consensus method could result in too many compromises for consistency and rationality (Bruce, William, Fred, Fred, \& Douglas, 2004).

In handling the challenges, I was influenced by Hoffmeyer et al. (2015) arguments. They stated that academics need to share innovations to effectively lead teaching teams and to promote quality-teaching experiences for students. Therefore, I encouraged both the programme team and advisory board to focus on their terms of references.

As part of the development process, I constructed a semi-structured interview schedule to ask staff, employers and the advisory board about the rationale, objectives, and importance of MHRM Programme, including what elements to introduce and what curriculum areas they might want to develop. I then interviewed each group member and everybody else who desired to talk to me. Accordingly, comprehensive information was made available to me, which created a basic subject analysis. In this data set, I identified significant areas of consensus on the strengths of the MHRM Programme. I led the process of programme design to ensure that we followed a rigorous plan. In developing the course descriptions, I made sure that ILOs were clearly described and measurable. I influenced the design to make sure students would be active as learners. This gave the programme a special flavor, which influenced recruitment, progression, and retention rates. I also made sure that we designed the programme to build good formative and summative assessment practices. As I led the change, I also consulted with current students to make sure that the plans we were making would be seen as positive. I was very happy to hear some very encouraging comments about the importance of lesson plans with clear learning outcomes, instructors being very supportive in terms of using technology, fair assessment, and using research output in the teaching and learning process.

Under my leadership, the programme team completed the first draft of the MHRM Programme proposal that considered aims, fitness for purpose, academic progression, curricular content, level, outcomes, assessment and graduates attributes, and included details as to how technology would be used to support student learning (Middlehurst, 2012). I presented the draft proposal of the MHRM Programme at the next development meeting of the Department's Programme and Curriculum Review Committee. During the meeting, I observed that some participants' views and suggestions were not related to the subject under discussion and were not contributing to the improvement of the programme. Hoffmeyer et al. (2015) argue that there is "a need for formal leaders and academics to reach agreement about evidence of effective leadership in learning and teaching". Therefore, I made every effort, to manage suggestions that were not effective and to encourage participants to concentrate on the proposals at hand. On reflection, the opportunities for a stress meeting were probably reduced. A week later, I received positive comments from participants in the meeting expressing support. This encouraged me to move forward. Accordingly, I organized regular discussions with the programme team to review the programme and identify the areas that required changes and took into consideration effective suggestion raised during the Programme and Curriculum Review Committee meeting. I allocated a leader for each course to develop the student learning 
experience. I planned that would empower the course leaders to be innovative within manageable boundaries. Some of the course leaders finished their task within a short period while others were late. However, with my help, the final version of the MHRM Programme was developed and the deadline was met.

My main goals were achieved. The MHRM Programme was developed on time and had broad support. One expert commented on the programme specification by saying that it provided a concise summary of the main features of the programme and the learning outcomes that a typical student might reasonably be expected to achieve and demonstrate if he/she takes full advantage of the learning opportunities that are provided. The programme was discussed and successfully approved at the department, college and university levels with minimum changes. The approval process of programme ensured that ASU policies, procedures, and regulations were applied effectively and consistently. The approach that I had initiated in developing the programme has since been adopted by ASU at a senior level and strategically implemented widely across the university. On reflection, I learned that it was important and beneficial during the development process of the MHRM Programme, to interview the stakeholders individually, allowing each one to state his/her opinions. The Programme received "full confidence" judgment from Bahrain QQA Programme Review in 2014.

In running the programme since its validation in 2014, my leadership was present and had impact upon learners. I supported the programme team to prepare documents such as action plans; operational plans and the annual programme review report (APRR) which were presented to the Programme External Examiner and we received positive comments. The external examiner has reported that academic staff are very competent and capable. He praised the used forms of assessment, including examinations, coursework assignments, and peer marking. His discussions with students confirmed their satisfaction with the programme and being able to learn. The programme has recruited students and has been proved successful as the number of intake students increased significantly in the last academic year by more than $50 \%$. The Deanship of Admission and Registration has confirmed this by reporting that MHRM students' enrolment, progression, retention, attrition, completion rates and length of study period meet specified targets. During preparation of the APPR, I had personal discussions with the students and they echoed that the programme really met their ambitions. Students considered the programme as a landmark in Bahrain. Currently, a considerable number of MHRM alumni hold senior positions in private companies and the public sector in Bahrain and other Gulf States.

I was successful in leading the team because I followed an active communication plan (Scott, Hamish \& Anderson, 2008). This meant that I engineered my meetings with updates and minutes taking, using e-mails, and regular meetings to discuss forthcoming changes, and to talk and inform my colleagues of best practices within the team. In one of the meetings, colleagues with different experience backgrounds expressed with joy how happy they were to be as informed and guided, reporting the positive effect on their performance and interactions which were very effective and fruitful. The high morale of the team helped tremendously in achieving the task and I learnt that informative and interactive leadership is a crucial part of managing change. 


\subsection{Case Study (2): Mentoring and the Development of Others}

Case Study 2 presents my leadership role as mentor, developer of others, supporter, disseminator, and facilitator. The following examples are evidences of my significant involvement and reflection in the said leadership themes. This includes mentoring and the support of new staff, mentoring the qualification placement on NQF at ASU, mentoring colleagues in developing the Balanced Scorecard Professional (BSC) at ASU, and mentoring colleagues working towards applying for the status of HEA Fellowship.

Regarding mentoring and the support of new staff, ASU expects that academics in the early stages of an academic career at the university should receive constructive advice on career development. In this context, I have been a mentor to newly appointed academic staff since 2013. My role as a mentor is of crucial importance for those newly appointed staff. It includes a programme of induction activities for new staff, so they understand the university and its approach to learning and teaching. My role as a mentor has been influenced by (Andrea, Lorelle, Sophie, \& Karen, 2013). They state that the role of the mentor is three-fold: to assist the mentee in developing an understanding of the expectations placed upon them as academics within the department, to provide a listening ear and informal guidance to the mentee, and to act as an advocate for mentee. I assumed responsibility to meet mentees regularly to discuss their progress towards satisfying the College's requirements for a successful provisional appraisal (Fiona, 2008). I advise new staff to refer to the university's criteria for good teaching practice that are available in the staff portal. To ensure the essence of the mentoring relationship, my duties include assisting new faculty to develop strong teaching techniques as well as the ability to critically reflect on their practice ( Aysenur, Jennifer, Greg, \& Oya, 2010); Crisp, 2010; D'Abate, 2009).

In addition, I supported new staff in setting exams, preparing course portfolios and course design. The impact has been great. One of the mentees remarked, "the mentoring process helped to develop my professional and personal growth through developmental guidance offered by my mentor who has the relevant skills, knowledge and experience". Another stated, "Mentoring helped me to figure out where I want to be and how I will get there". In addition, I have mentored one of my colleagues in writing research for symposiums and forums. He expressed his happiness regarding my support when his first article was accepted for publication. Therefore, my relationship was a positive and trusting one. I think both of us (mentor and mentee) benefit from the relationship. This mentoring process gave me a good chance of "give back" -- to both the ASU and to the mentees. It helped me to remember the importance of listening actively rather than passively. In addition, it inspired me to exchange knowledge, which helped increase the mentee's confidence and created strong ties of relationships with colleagues at different levels. My knowledge of ASU became wider and I felt better in terms of belonging and satisfaction. In addition, the mentoring process with the initiated supporting material have been implemented widely across the university.

As for mentoring the Qualification Placement on National Qualifications Framework (NQF) at ASU, the National Qualifications Framework was established to contribute to education reform in the Kingdom of Bahrain in 2015. I lead a Qualification Placement exercise. As such, 
my overall aim was the development of a relevant, coherent, and deliverable Qualification Placement within the required time scales. This example explores my collaboration with stakeholders, especially staff, to this end. Accordingly, I led, supported, supervised, managed, and mentored my colleagues in the Business Administration Department to map the Bachelors in Business Administration Programme to NQF levels using the NQF descriptors. I began the process by conducting two workshops. The purpose of the workshops was to ensure that all participants had a practical working knowledge of Bahrain's NQF and the requirements for submission of qualifications for consideration and placement on the framework. The expected outcomes at the end of the training were that all participants would be able to firstly state the purpose and value of the NQF. Secondly, they access and be familiar with the NQF website, its organisation structure and available documentation and application forms. Thirdly, they recognise the purpose, requirements, and benefits of institutional listing. Fourthly, to recognise the requirements for qualifications to be proposed for placement consideration on the NQF. Finally, they recognise the function and role of mapping qualifications. The first workshop addressed the mapping process, which included the role of the faculty members, the qualification placement application form, the mapping panels, and the confirmation panel. In the second workshop, I presented a mapping exercise that included mapping scorecard, course specification form, NQF levels and credit and NQF descriptors. Both workshops were well attended, and the impact was great where all participants were able to practise writing learning outcomes, devising assessment, calculating notional learning hours, and mapping qualifications to the NQF level descriptors. I received excellent evaluations from colleagues. I also developed a mapping scorecard for the Business Ethics Course to support the qualification placement on NQF process. The University Quality Assurance and Accreditation Centre (QAAC) praised the developments I initiated, and they have been adopted and implemented widely across the university as an example of effective practice. I also mentored the faculty members during the mapping of the courses assigned to them using the Course Specification Form and the Mapping Scorecard. However, my reflections on this area of the workshop as informed by faculty member feedback identified a further problem regarding how to calculate NQF credit hours through notional hours. I addressed this by getting staff to work in pairs to allow them to learn from each other. The feedback has been very positive. I have also shared this development with the other groups within the university as an example of how I have used reflective practice to respond to a problem to produce effective outcomes.

In terms of mentoring colleagues in developing Balanced Scorecard Professional (BSP) at ASU, I remember well in 2013, when I was teaching the strategic management course, I wrote a proposal to the university president about the importance of attending a Balanced Scorecard Workshop. The Balanced Scorecard Professional is an integrated strategic planning and management system. The goals of the workshop were to: learn a framework for building and implementing a strategic performance scorecard system, learn about change management aspects of the balanced scorecard journey, learn how to communicate a strategic planning around a balanced scorecard initiative, and learn how to overcome challenges to success and how to translate balanced scorecard theory into practice. The university president accepted my proposal and I attended the workshop in Abu Dhabi. After the completion of Balanced Scorecard Workshop, I sat an online exam where I attained the Balanced Scorecard 
Professional (BSP) Certification. The Balanced Scorecard Institute and George Washington University College of Professional Studies jointly issued the (BSP) Certification. I suggested to the university president that to conduct a Balanced Scorecard workshop. Academic and administrative staff attended it. The workshop focused on the development of an integrated strategic planning and management system based on the balanced scorecard. At the end of the workshop, I received positive comments from the participants and I got support from the university president. I then encouraged the participants to start building the BSC framework, under my supervision, into their specialization to improve the strategic planning process of the university (Campbell, Smith, Dugan, \& Komives, 2012). Since then the university has adopted and implemented my ideas widely across the university. This was a challenging task for me and I benefited a lot from colleagues' comments and questions at the workshop. There is evidence of impact. For example, I was told by one of my colleagues who teaches in the MHRM Programme that he has incorporated the balanced scorecard as part of the course specifications (Strategic Human Resource Management) through the curriculum committee at the department and college levels. In addition, I supervised two of our master's students who have addressed the balanced scorecard as an area of research for their master theses. I felt very satisfied that I was able to impact and contribute to change effectively at university level and to disseminate BSC to our colleagues. The senior management team invited me and praised me for this distinguished contribution.

Concerning mentoring colleagues working towards applying for the Status of HEA Fellowship, ASU has a policy supporting its academic staff in gaining formal recognition for quality-enhanced approaches to teaching and supporting learning. Accordingly, the first group successfully achieved the status of Fellow or Senior Fellow of the HEA. Currently, the second group is in the process, which includes those who achieved the status of Fellow and are now applying for the status of Senior Fellow. In addition, it includes those who are applying for the status of Fellow.

Having successfully achieved the status of Senior Fellow of the HEA, I took a leading role in action research as a part of the training process for those working towards applying for the status of Fellow. I delivered a presentation on action research under the supervision of a HEA trainer who provided very useful comments at the end of the session (Antonellis \& Berry, 2017). These valuable remarks made me more confident and encouraged me to be engaged in mentoring my colleagues in preparing their own action research. Having conducted successful action research in fair and true assessment, I am known as a supporter of HEA applicants. I have also conducted workshops on dimensions of the HEA Framework (Areas of Activity, Core Knowledge, and Professional Values) for those likely to be at Descriptor 2. Moreover, I have led my colleagues in developing their own action research in areas such as contemporary pedagogies (ICP), individual tutorials, working in pairs and peer review. In addition, I led them during the writing of their applications for FHEA. I worked closely with two of my colleagues on how to prepare their fellowship applications. In doing that, I guided them during writing the five areas. Aggie and Leone (2015) who reported benefits and outcomes on mentors and mentees feedback on the value of participating in the structured mentoring programme such as gaining a fresh perspective on career development and promoting the transfer of knowledge 
influenced me. Accordingly, I encouraged my mentees to think more about an issue and to explore it in more depth, thus, leading to a deeper level of reflection. In addition, I invited my mentees to introduce new ideas and make suggestions (hypothetical), and asked them to obtain further information on reasons, attitudes, and feelings (justifying). Moreover, I helped them to discover motivations, feelings, and hidden concerns (searching). Lastly, I ensured that my mentees had clearly understood the process and requirements for applying for HEA fellowship (checking) (Colvin \& Ashman, 2010; Crisp, 2011; Crisp \& Cruz, 2009; De Janasz \& Sullivan, 2004). However, during the mentoring process, I observed that listening is never easy, for example, one of the mentees did not seem to listen carefully to me. I acknowledge that it was my problem and I had to do something. Accordingly, I had a private conversation with him where I used reflective, summarizing and appreciation statements that helped me to address this issue.

These activities have had a significant impact on my professional practice and development of other colleagues (my mentees) and in turn the development and preparation of their application for HEA fellowship. This experience reflected on the teaching and learning, and it broadened my scope in being an efficient mentor who can provide help and guidance to all colleagues in need for professional development. My mentees told me that my support helped finish their application successfully and I gained good experience in supporting others. Our students in meetings mentioned this and praised the positive change in teaching and learning (Rosalyn, Vivien, \& Ruth, 2014; Nora \& Crisp, 2007).

\section{Conclusion}

This paper presents lessons drawn from senior fellowship of the Higher Education Academy, United Kingdom (SFHEA) with regard to leadership and mentoring. The paper integrated various elements of leadership and mentoring that needed for enhancing the quality of teaching and learning in Higher Education. The paper highlighted the content and context of leadership of teaching (by explicitly including knowledge and evidence related to teaching and learning) for student learning.

In this article, I have shared my teaching and supporting learning experience (almost 35 years) in higher education as inspired from the SFHEA, UK. Evidence of my successful engagement across all five areas of activity was provided that include firstly, designing a series of teaching and learning activities to meet the learning outcomes of a module. Secondly, using a range of teaching approaches to enhancing student learning. Thirdly, using a variety of assessment for learning activities for students and providing feedback to promoting student engagement fourthly, developing effective learning environments and approaches to student support and guidance. Fifthly, engaging in continuing professional development (CPD) in subjects /disciplines and their pedagogy, incorporating research, scholarship and the evaluation of professional practices. Moreover, it provided an understanding of the appropriate core knowledge and demonstrating my commitment to the professional values.

Moreover, the UK Professional Standards Framework for teaching and supporting learning in higher education (the five areas of activity, core knowledge and professional values) was applied through a personal and academic experience and leadership within is UKPSF that 
pointed towards further development in my leadership and mentoring roles in higher education.

The reflection in own practice and obtaining FHEA and SFHEA helped in thinking about professional practice. It also confirmed that working in many different ways influence what is happening in Higher Education institutions, for its staff and students.

This paper contributes by providing and demonstrating a thorough understanding of effective approaches to learning and teaching support as a key contribution to high quality student learning. In addition to providing evidences of successful leadership, co-ordination, support, supervision, management and/or mentoring of others (whether individuals and/or teams) in relation to learning and teaching.

\section{Implications}

The article has implications for new faculty members in building their competences of effective approaches to teaching and learning support as key contributions to high quality student learning. In addition, this article assists those professors who are planning to apply for the valuable and prestigious fellowship or senior fellowship of the Higher Education Academy, United Kingdom.

\section{References}

Abdeldayem, M. (2018). Teaching Philosophy and Learning Support in Higher Education as inspired from the Senior Fellowship of the Higher Education Academy, UK: A Case Study from Bahrain. Social Science Learning Education Journal, Vol. (3), No. (6), Pp. 77-84.

Aggie, L., \& Leone, C. (2015). UWS Academic Mentoring Program. [Online] Available: https://www.westernsydney.edu.au/_data/assets/pdf_file/0006/970386/2014_Executive_Sum mary_-_Academic_Mentoring.pdf.

Andrea, C., Lorelle, J. B., Sophie, X., \& Karen, E. (2013). Peer mentoring: Supporting successful transition for first year undergraduate psychology students. Australian Journal of Psychology, (65), 30-37. https://doi.org/10.1111/ajpy.12006.

Antonellis, P., \& Berry, G. (2017). Practical Steps for the Utilization of Action Research in Your Organization: A Qualitative Approach for Non-Academic Research. International Journal of Human Resource Studies, 7(2), 41-59. https://doi.org/10.5296/ijhrs.v7i2.10942.

Aysenur, B., Jennifer, M. T., Greg, J. N., \& Oya, Y. G. (2010). The mentoring relationship: A comparison of counselling students in the United States of America and Turkey. Counselling Psychology Quarterly, 23(4), pp. 387-398. https://doi.org/10.1080/09515070.2010.529677.

Bruce, J. A., William, L., Fred, O. W., Fred, L., \& Douglas, R. M. (2004). Unlocking the mask: A look at the process by which authentic leaders impact follower attitudes and behaviors. The Leadership Quarterly, 15(6), (December 2004), 801-823. https://doi.10.1016/j.leaqua.2004.09.003.

Bryman, A. (2007). Effective Leadership in Higher Education: Summary of findings. Research and development series. Leadership Foundation for Higher Education, UK. 
Campbell, C. M., Smith, M., Dugan, J. P., \& Komives, S. R. (2012). Mentors and College Student Leadership Outcomes: The Importance of Position and Process. Review of Higher Education, 35(4), pp. 595-625.

Cindy, B. (2004). Models of Mentoring in Communication. Communication Education Journal, 53(1). https://doi.org/10.1080/0363452032000135779.

Colvin, J. W., \& Ashman, M. (2010). Roles, Risks, and Benefits of Peer Mentoring Relationships in Higher Education. Mentoring \& Tutoring: Partnership in Learning, 18(2), 121-134.

Crisp, G. (2011). The impact of mentoring on the persistence decisions of undergraduate students attending a Hispanic Serving Institution. Enrollment Management Journal: Student Access, Finance and Success in Higher Education, 5(1), 32-57.

Crisp, G., \& Cruz, I. (2009). Mentoring College Students: A Critical Review of the Literature between 1990 and 2007. Research in Higher Education, 50(6), 525-545.

Crisp, G. (2010). The impact of mentoring on the success of community college students. The Review of Higher Education, 34(1), 39-60. https://doi.org/10.1353/rhe.2010.0003.

D'Abate, C. P. (2009). Defining Mentoring in the First-Year Experience: One Institution's Approach to Clarifying the Meaning of Mentoring First-Year Students. Journal of the First-Year Experience \& Students in Transition, 21(1), 65-91.

De Janasz, S. C., \& Sullivan, S. E. (2004). Multiple mentoring in academe: Developing the professional network. Journal of Vocational Behavior, 64(2), 263-283.

Dietz, A. J., Jansen, J.D., \& Wadee, A. A., (2006). Effective PhD supervision and mentorship: A workbook based on experiences from South Africa and Netherlands. South Africa-Netherlands research Programme on Alternatives in Development (SANPAD).

Fiona J. (2008). From expert to novice: An exploration of the experiences of new academic staff to a department of adult nursing studies. Nurse Education Today, 28(4), 401-408. https://doi.org/10.1016/j.nedt.2007.07.004

Gary A. O. (2008). The Importance of External Boards: The Chronicle of Higher Education. [Online] Available: https://www.chronicle.com/article/The-Importance-of-External/45960.

General Directorate of National Qualifications Framework (2015). National Qualifications Framework: Handbook for Institutions. Kingdom of Bahrain.

George B., \& Colin W. (1995). Leaning into the Future: Changing the Way People Change Organizations. Nicholas Brealey Publishing Ltd.

Hoffmeyer, A., Sheingold, B., Hester, C., Klopper, H., \& Warland, J. (2015). Leadership in Learning and Teaching in Higher Education: Perspectives of Academics in Non-Formal Leadership Roles. Contemporary Issues in Education Research - Third Quarter, 8(3), 181-192. https://doi:10.13140/RG.2.1.1383.7924 
Khaled, G., Bassam, H., Haythem, B., Asem, Z., Ahmed, S., Noel, M., \& Conor B. (2012). Review and redesign of the curriculum of a Master's programme in telecommunications engineering - Towards an outcome-based approach. European Journal of Engineering Education , 38(2), 194-210. https://doi.org/10.1080/03043797.2013.766674.

Lorraine, A., Eric M., Elena D. R., \& Monica, M. (2016). Capturing Learning Gain from Work Placements, University of Dundee. Retrieved from https://www.heacademy.ac.uk/system/files/downloads/vcsei_dundee_hea-learning-gain-repor t-june2016_fv_la.pdf

Middlehurst, R. (2012). Leadership and Management in Higher Education: A Research Perspective Working Paper No. 2012/47 prepared for the Maastricht School of Management's research seminar on Leadership and Management in Higher Education, held in Maastricht. Retrieved from http://ftp.repec.org/opt/ReDIF/RePEc/msm/wpaper/MSM-WP2012-47.pdf.

Nora, A., \& Crisp, G. (2007). Mentoring students: Conceptualizing and validating the multi-dimensions of a support system. Journal of College Student Retention: Research, Theory and Practice, 9(3), 337-356. https://doi.org/10.2190/CS.9.3.e.

Pegg, A. Waldock, J. Sonia, H. \& Lawton, R. (2012). Pedagogy for employability. Higher Education Academy, UK. [Online] Available: https://www.heacademy.ac.uk/system/files/pedagogy_for_employability_update_2012.pdf.

Quinlan, K. M. (2014). Leadership of teaching for student learning in higher education: what is needed? Higher Education Research \& Development, 33(1), 32-45. https://doi.org/10.1080/07294360.2013.864609

Richard, B., Georgy, P., \& Jonathan, G. (2007). Tensions in Higher Education Leadership: Towards a Multi-Level Model of Leadership Practice, Centre for Leadership Studies, University of Exeter. Paper presented at the Annual Conference of the Society for Research into Higher Education. Retrieved from https://pdfs.semanticscholar.org/15b1/9974b8849609a245a151fc3c376ea26364ca.pdf

Rosalyn, C., Vivien, S. \& Ruth, W. (2014). The impact of peer mentoring on levels of student wellbeing, integration and retention: a controlled comparative evaluation of residential students in UK higher education. Higher Education, 68(6), 927-942. https://doi.org/10.1007/s10734-014-9752-y

Sally, B., (2007). Feedback and Feed-forward. Centre for Bioscience, Bulletin, 22. Retrieved from www.bioscience.heacademy.ac.uk

Savage, H. E., Rashelle, S. K., \& Logue, R. (2010). Faculty Mentorship at Colleges and Universities. College Teaching, 52(1), 21-24. https://doi.org/10.3200/CTCH.52.1.21-24.

Scott, G., Hamish C., \& Anderson, M. (2008). Learning leaders in times of change: Academic Leadership Capabilities for Australian Higher Education. Retrieved from https://research.acer.edu.au/cgi/viewcontent.cgi?article=1001\&context=higher_education

Sharon, B., Roland, C., Jerrold R. C., \& Leroi, B. D. (2010). Common misconceptions of 


\section{Macrothink}

International Journal of Learning and Development

ISSN 2164-4063 2019, Vol. 9, No. 1

critical thinking. Journal of Curriculum Studies, 31(3), 269-283. https://doi.org/10.1080/002202799183124.

Siddique, A., Aslam, H., Khan, M. \& Urooj F. (2011). Impact of Academic Leadership on Faculty's Motivation, and Organizational Effectiveness in Higher Education System. International Journal of Business and Social Science, vol. 2, no. 8, pp. 184-191. [Online] Available http://www.ijbssnet.com/journals/vol. 2,no. 8, \%3B_May_2011/23.pdf.

Simon, A. B. (2015). Qualities of Effective Leadership in Higher Education. Open Journal of Leadership, 04(02), 54-66. https://doi.org/10.4236/oj1.2015.42006.

\section{Copyright Disclaimer}

Copyright for this article is retained by the author(s), with first publication rights granted to the journal.

This is an open-access article distributed under the terms and conditions of the Creative Commons Attribution license (http://creativecommons.org/licenses/by/4.0/). 